DOI: $10.24234 /$ wisdom.v17i1.422

Tetiana KOROLOVA,

Oleksandra POPOVA, Natalya ZHMAYEVA

\title{
INTERPRETATION OF THE CHINESE PRESS AND FEATURES OF ITS TRANSLATION INTO UKRAINIAN
}

\begin{abstract}
The paper develops a methodology for interpreting and analysing translation features (including strategies, tactics, and operations) of the Chinese press within the language pair "Chinese - Ukrainian". Special attention is paid to the lexical and grammatical characteristics of the Chinese press as manipulative instruments. The philosophical background of the Chinese newspaper lexicon is considered, which stipulates a diverse use of standard and specific vocabulary (including terms) from modern Chinese (白话 / báihuà), idiomatic expressions (成语 / chéngyǔ), neologisms and literary words from old Chinese (文语 / wényǔ), and emotionally coloured vocabulary. The grammatical level is represented by fixed word order in a sentence; complex, compound, and two-member simple sentences; all communicative types of sentences; lack of elliptical structures; a large number of particles. The research offers an integrated approach to the study of the strategy of communicatively equivalent translation, translation tactics, and operations when dealing with the Chinese press. Some translation regularities are illustrated.
\end{abstract}

Keywords: Chinese press, lexical and grammatical characteristics, translation, manipulation, interpretation, Ukrainian.

Introduction

Nowadays, mass media seem to be a powerful means of manipulation and an only source of diverse information which covers all spheres of people's life. Media technologies aim at reaching a large audience for communicating. In this respect, we can state that due to rapid technological progress, we are pressed for time and require information every minute. This is why broadcast (films, radio, recorded music, television) and digital (the Internet and mobile mass communication) media have nearly ousted the print ones. However, outdoor media contributes to transmitting information via such media as $\mathrm{AR}$ advertising, billboards; flying billboards; blimps; placards placed inside and outside buses, commercial buildings, shops, sports stadiums, subway cars, trains, etc.; skywriting, etc.

It should be mentioned that the generation of the $1960^{\text {th }}$ and the further one has got used to getting information from print media (books, comics, magazines, newspapers, pamphlets, etc.). They experience discomfort when dealing with digital media and continue obtaining necessary information from print media. Still, people who live under current social conditions (it does not matter whether they are young or old) have 
been adapting to the new realities and life modes for more than half a century. We can assume that digital mobile (cell) phones belong to the most popular multifunctional mass media today, which support a variety of services, such as text messaging, MMS, digital photography and video games, Internet access, email, short-range wireless communications (infrared, Bluetooth), business applications, etc. Despite having an opportunity to use all of these services, we can support the opinion of the Ukrainian scholars (O. Polishchuk, I. Vitiuk, N. Kovtun and V. Fed) regarding "an increase in information chaos in the modern symbolic production and exchange and a person's confusion when meeting a large number of information" (Polishchuk, Vitiuk, Kovtun, \& Fed, 2020, p. 45). The other mass media can be placed in this order of popularity introduction: The Internet, Television, radio, cinema, recordings (gramophone records, cassettes, magnetic tapes, cartridges, CDs, and DVDs), printed press.

Magazines and newspapers (periodical publications containing various articles and advertisements) enrich our lives with diverse information. Scientific, artistic, academic or unique interest-related issues are published in magazines, whereas the most important function of newspapers is to inform the public of significant events (Pavlik \& McIntosh, 2017). It should be noted that the Internet has challenged the press as an alternative source of information and opinion but has also provided a new platform for newspaper organisations to reach new audiences (World Trends in Freedom of Expression and Media Development, 2018). According to the World Trends Report, between 2012 and 2016, print newspaper circulation continued to fall in almost all regions, except Asia and the Pacific, whereas India's print circulation grew by 89 per cent (Campbell, 2017). Nevertheless, advertising revenue makes up the bulk of a newspaper's income, and print media are shifting from print to online, enabling us to confirm that the Internet, radio and television have not entirely supplanted the existing printed press. Therefore, the role of the printed press is important.

The current development rate of international relations increases the need to acquaint representatives of various professions with publicism (political or topical journalism) originated in different countries. Alongside English-language publications, Chinese-language periodicals are in great demand today, since one can find there urgent issues concerning a big number of Chinese people's achievements in nearly all spheres of life - social, political, economic, cultural, scientific, etc. Taking into consideration the fact that the Chinese language is not studied in schools or universities around the world as actively as English, consumers look for the possibilities of getting information from translated versions of the Chinese press. This is the reason why scholars specialised in the field of communication, linguistics and translation studies should pay special attention to the problems related to translation peculiarities of the Chinese press into different languages. Another reason why it is topical to study linguistic and translation-related features of the Chinese press is The 'Belt and Road' Initiative and The 'New Silk Road' Project, which determine further vectors of China's development and its international cooperation.

Chinese is under the focus of the Ukrainian linguists who research different areas as follows: they identify typologically standard and distinctive features of Chinese compared to other languages (Deng \& Liu, 1989; Samovar, Porter, \& Stefani, 2000; Zhang, Anderson, Li, Dong, Wu, $\&$ Zhang, 2010); analyse the features of translation operations when dealing with Chinese (Ko- 
rolova \& Aleksyeyev, 2018; Sdobnikov, 2015; Korolova, Popova, \& Ding, 2014); characterise the inventory and taxonomic composition of the Chinese language, its dialects (Vorotkov, 1968; Klyenin \& Shchichko, 1978; Ruda, 2017; Frolova, 1981; Khamatova, 1981); study the philosophical problems of Chinese writing (Guo \& Liu, 1997; Samovar, Porter, \& Stefani, 2000), the pragmatics of Chinese communication $(\mathrm{Ru}-$ da, 2017) and many other issues.

The relevance of the article is stipulated by the interest of linguists in the problems of adequate translation of non-closely related languages (in our case Chinese and Ukrainian), as well as lack of research in this field of linguistics and lack of systematisation of empirical indicators of relevant translation operations, tactics, and strategies when dealing with Chinese.

Theoretical Framework: Integrating the Printed Press Evolution with the Linguistic

Characteristics of the Chinese Press and its Translation Techniques

The notion 'press' has acquired a range of interpretations in the course of its development from the previous centuries to the modern days of digital technologies. Nowadays, its understanding serves as theoretical groundings for modern classifications of print media and a platform for various interdisciplinary perspectives.

The term 'print press' has several synonymic expressions - print media, print-based media, print media, etc. In dictionaries, the term 'print media' is defined in these ways:

- "the part of the press using printed media, such as newspapers, as opposed to audiovisual media" (Your Dictionary, n.d.);

- "broadly, any written or pictorial form of communication produced mechanically or electronically using printing, photocopying, or digital methods from which multiple copies can be made through automated processses; more narrowly, any form of 'ink and paper' communication that is not hand-written or hand-typed, including books, circulars, journals, lithographs, memos, magazines, newspapers, pamphlets, and periodicals" (Oxford Reference, n.d.);

- "all forms of communication - newspapers, journals, and magazines - that are delivered by physical print; the prolific and traditional medium for advertising" (Doyle, 2011, p. 69);

- "a way of referring to newspapers and magazines" (Combley, 2011, p. 655);

- "newspapers and magazines" (Macmillan English Dictionary, n.d.), etc.

Christiane Eilders (2016) associates print media with traditional mass media published on paper. We support the author's ideas as listed below:

"The concept not only includes the published products but also regards the organisational context shaping the journalistic routines and norms behind the printed products. Print media represents the oldest and the most widespread type of mass media because as opposed to electronic media it does not require an elaborate technical infrastructure on the part of the user. It mainly comprises newspapers and magazines. Newspapers are clearly associated with information and show an emphasis on political issues and current events. They are valued as a backbone of the democratic public sphere because they enable comprehensive public discourse. News magazines also serve an information function, whereas most other magazines are morecommitted to entertainment and leisure. 
These magazines show a diverse spectrum ranging from lifestyle to special interest magazines. With the rise of online communication print newspapers and magazines have come under considerable economic pressure" (Eilders, 2016).

Printed media have their evolution. J. J. Spielvogel gives an overview of the printed press evolution:

"The printing press was invented in the Holy Roman Empire by the German Johannes Gutenberg around 1440, based on existing screw presses. Gutenberg, a goldsmith by profession, developed a complete printing system that perfected the printing process through all of its stages by adapting existing technologies to printing purposes, as well as making groundbreaking inventions of his own. His newly devised hand mould made possible for the first time the precise and rapid creation of movable metal type in large quantities, a key element in the profitability of the whole printing enterprise" (Spielvogel, 2010).

According to the viewpoints delivered by HISTORY.COM editors, the printing press was created in China, and it "revolutionised society there before being further developed in Europe in the 15th Century by Johannes Gutenberg and his invention of the Gutenberg press" (Printing Press, 2018). "The Diamond Sutra", a Buddhist book from Dunhuang, China, from around 868 $\mathrm{AD}$ during the Tang Dynasty, is believed to be the oldest known printed book (at that time, rolled-up scrolls began to be replaced by bookformatted texts). Another book - "Nung Shu" is considered the world's first mass-produced book, which documented many Chinese inventions. It was exported to Europe and contained the information that, coincidentally, attributed to Europeans.

Patricia Buckley Ebrey, in her book "The
Cambridge Illustrated History of China" (2010), traces the origins of Chinese culture from prehistoric times to the present (from the rise of Confucianism, Buddhism, and the great imperial dynasties to the Mongol, Manchu, Western intrusions, and the modern communist state). Her scope embraces Chinese arts, culture, economics, society and its treatment of women, foreign policy, emigration, and politics, including the critical uprisings of 1919 and 1989 in Tiananmen Square (Ebrey, 2010). Needham and Tsien (1985) give the most comprehensive account of every aspect of paper and printing in China to be published in the West and study the invention, technology and aesthetic development of printing in China. Professor Tsien carries the story forward to the beginning of the nineteenth century when "more printed pages existed in Chinese than in all other languages put together" (Needham \& Tsien, 1985). At the beginning of the twentieth century, the main requirements to the printed products were established: the regularity of each letter, the compactness of each line, the closely woven pattern of each page, comparable to a latticed gothic window or an oriental carpet (Steinberg \& Warde, 2017).

When dealing with the mass media discourse, one should be conscious of its typological characteristics: pragmatism, practical orientation, manipulation. It should be noted that mass media comprise publicistic (journalistic) texts that 'obey' the rules of the publicistic style. Thus, the general aims of the publicistic style are:

- to influence the public opinion;

- to convince the reader / the listener that the interpretation of the information given by the author is the only correct one;

- to make the audience accept the expressed viewpoint(s) (Erofeeva \& Ushnikova, 2017). The publicistic style comprises these 
subdivisions: journalistic articles; essays, including their shorter (on philosophical, social, aesthetic, or literary subjects) and longer (reviews, memoirs, treatises) forms; oratorical radio, and TV commentary.

In our opinion, linguistic peculiarities are of great importance in text production (alongside extralinguistic ones). Authors are to build texts, depending on subject-matter and the type of a publicistic (journalistic) text. Texts written in Chinese deserve special attention as non-native speakers encounter many difficulties decoding hieroglyphs-symbols that look alike (Chinese 成/chéng - [to be a success], 戊/ wù - [the fifth], 戌 shù-[border guard service], 戎/ róng - [weapon], 戊 $x \bar{u}-$ [the eleventh terrestrial branch], on the one hand; and determining their semantics, on the other hand. Another factor to be taken into consideration is homonymy (Khamatova, 1981) that is a wide-spread phenomenon in the Chinese language (e. g., 丁ding - [an experienced, senior worker] and Jding / Ding, a Chinese surname; 想/ xiăng - [to think, to consider, to speculate] and 䐟 /xiăng - [fat; plump, bent; curved feet]. Conversion (or transposition) in Chinese impedes the understanding of the text semantics. The use of 文言/wényán words (wényán, from wén writing + yán speech, words) in the Chinese press is widespread. These words constitute 'the literary Chinese' (or 文言 / Wényán). “The literary Chinese” includes both 古文/ gǔwén (the written language of the ancient classics) and modern writings with classical grammar and syntax, which complicates the deciphering of hieroglyphs; whereas 白话 / Báihuà modern spoken Chinese - seems to be a clear plain language.

Hence, it is expedient to pay attention to the specific linguistic features of Chinese against the background of the extralinguistic ones when translating the Chinese press. The more aware of the linguistic and extralinguistic features a translator is, the more adequate translation he/she makes. It should also be mentioned that the translation result depends on the chosen strategies, tactics, and operations. In this respect, we associate 'translation strategy' with a program aimed at the implementation of translation activities formed on the basis of the translator's interest in quality translation. We define 'translation tactics' as "an integrated set of translation operations performed within the framework of the implementation of the chosen translation strategy" (Popova, 2019, p. 153); 'translation operation' is interpreted as "a specific action of the translator in the process of reproducing the original (source) text in the target language" (Popova, 2019, p. 153). The detailed analysis of the linguistic features of the Chinese press and its translation peculiarities are specified in further paragraphs.

\section{Material and Methodology}

As far as the translation techniques of the Chinese press is concerned, the focus is on the selected publicistic articles. The research material covers newspaper articles in Chinese (and their translated versions in Ukrainian) taken from the Chinese official print edition of the Central Committee of the Communist Party of China $ᄉ$ 民日報 / rénmín ribào (Eng. People's Daily (PRC newspaper). In total, 43 pages of the original Chinese text and 48 pages of their Ukrainian versions were analysed with the help of qualitative and quantitative content analyses alongside translation analysis.

The paper aims at analysing translation peculiarities of the modern Chinese press into Ukrainian, which puts forward the tasks as follows: 
1) to analyse the linguistic characteristics of the Chinese press; 2) to provide analysis of translation operations, tactics, and strategies used while reproducing Chinese newspaper texts in Ukrainian.

Relying on the methodological tools of translatology, we use the following methodological procedure to process the data:

Step 1. Using linguistic analysis to spot and characterise all lexical and grammatical units typical of the Chinese press.

Step 2. Describing and interpreting lexical and grammatical features of the material under study within the Chinese media discourse with the help of qualitative content analysis.

Step 3. Using translation analysis to determine adequate translation strategies, tactics, and operations, which are used when translating the material under consideration into Ukrainian.

Step 4. Using computational analysis to count the revealed translation tools in order to determine the most commonly used ones.

The People's Daily usually employs 'writing task groups' which are published under their pen names (Bandurski, 2010; Gitter \& Fang, 2018). Let us consider some of them (see Illustration 1):

1) Chinese 任仲平 / Ren Zhongping - [Eng. 'Important People's Daily commentary']. It represents the view of the People's Daily as an organisation.

2) Chinese 钟声/Zhong Sheng - [Eng. 'Voice of China']. Its editors and staff give commentary on major international affairs.

3) Chinese 国纪平/ Guo Jiping - [Eng. 'Important Commentary on International Matters']. 国纪平/ Guo Jiping is meant to outline China's stance and viewpoints on major international issues.

4) Chinese 国平/Guo Ping - [Eng. 'Coun- try's Peace']. The edition focuses on $\mathrm{Xi}$ Jinping and his political thought.

5) Chinese 仲祖文 / Zhong Zuwen - [Eng. 'Articles from the Central Party Organization Department']. Articles published there cover topics related to the Party principles and ideology.

6) Chinese 郑青原/ Zheng Qingyuan - [Eng. 'clarify matters and get to the bottom of things']. It is aimed at commenting on political reforms.

7) Chinese 唐晓文 / Tang Xiaowen - [Eng. 'Party School writing']. It contains the articles written by the Central Party School editorials during the Cultural Revolution.

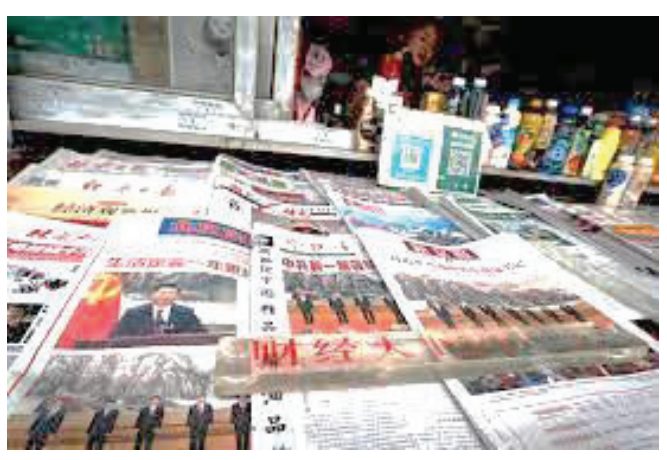

Illustration $1 .{ }^{1}$

In our research, we accept the viewpoint of R. Mirzakhanyan, S. Gevorgyan, V. Karapetyan, A. Dallakyan, A. Berberyan concerning "the contradictions of psychological character the manifestation of which more explicitly help to detect the presence or absence of dissonance or consonance in concrete situations and conditi-

1 Picture is available at: https://www.google.com/search? $\mathrm{q}=$ Ren + Zhong + Ping $+\% \mathrm{E} 4 \% \mathrm{BB} \% \mathrm{BB} \% \mathrm{E} 4 \% \mathrm{~B}$ B\%B2\%E5\%B9\%B3+site\&sxsrf=ALeKk03BwiXzRdtXmRuvWC4YmGO3trvWUw:1595936805572 $\&$ tbm $=i$ isch \&source $=i u \& i c t x=1 \&$ fir $=d D k K F i 5 y k Z z$ AwM\%252CKzjwDs00I9g02M\%252C_\&vet=1\&u sg=AI4 -kRK6qU3iZAJqXrp9AkeP3SḦkPjtMg\&s$\mathrm{a}=$ X\&ved=2ahUKEwiQ3YTz7-qAhVdRhUIHZiNBisQ9QEwCHoECAoQBQ \&biw $=1366 \&$ bih $=657$ \#imgrc $=$ ELGBFe5jwRG_1M. 
ons" (Mirzakhanyan, Gevorgyan, Karapetyan, Dallakyan, \& Berberyan, 2019, p. 76). In any press variety, authors must not express purely subjective personal judgments within the mass media discourse or be self-guided by the socalled pseudo-judgments "which do not correspond to the context given, especially in the cases when the person tries to conceal the reality connected with some conditions or situations" (Mirzakhanyan, Gevorgyan, Karapetyan, Dallakyan, \& Berberyan, 2019, p. 76). As for the Chinese press, a reporter/author must follow strict instructions related to the Governmental political course and mass media ethics. It is relevant from the practical conclusions of other Armenian scholars (Hasmik Hovhannisyan, Hovhannes Hovhannisyan, Astghik Petrosyan) that one can refer employee's lack of practice and too much focus on theoretical (or outdated) knowledge to the labour market disadvantages (Hovhannisyan, Hovhannisyan, \& Petrosyan, 2018).

Let us transform the studied issues into the framework of the Chinese periodicals. There are several types of newspaper articles. In this paper, they are considered depending on the ratio of the volume and nature of the topic (in compliance with the Ukrainian newspaper material). The primary type of Chinese newspaper materials under study include these articles: 评论/ pinglùn [Eng. 'commentary'], another name 述评 / shùping. These Chinese articles correspond to the Ukrainian journalistic works as follows: 1) a political commentator's article, a review; 2) 社论/shèlùn [Eng. 'leading article, editorial']; 3) 短评 / duănping [Eng. "short commentary", "brief comment", "small comment", 'short review'] (in the Ukrainian press, this type of articles is associated with journalistic notes dealing with international topics; they are often called the commentator's column); 4) 时评/ shiping [Eng. ' $a$ critical article on the topic of the day', 'journalism', 'news commentaries'] (its full name is 国 际 时事 评论 / guójì shishì pínglùn [Eng. 'a journalistic note on an international topic']).

The informative function of newspaper materials, as well as news reports in the fields of politics, science, sports, and public life, is realised through a large number of language tools at different levels of the language system. Along with the elements of standard colloquial language, depending on the content of the message, there are fragments of business language, various scientific professional languages, social and political terminology, unique vocabulary from various fields of science and professional circles, as well as a large number of proper names, such as geographical names or names of institutions and organisations. Another task of newspaper materials is to convey or promote information about scientific achievements, technical news, social and economic issues in an accessible way. Due to the diversity of such information, these functions are implemented through the updating of various language subsystems and professional languages. There are various means of expression, including stylistically marked bookish elements.

The pragmatic function of newspaper articles combines all the features of the compositional and semantic content of messages in order to have a specific impact on the reader, to convince $\mathrm{him} / \mathrm{her}$ of the correctness of the material provided, and to make the recipient have the same opinion as the author does, which correlates with a kind of manipulation. We support the viewpoints (Moratón \& Lavid, 2018) that authors/writers express a textual "voice" or a community recognised personality; present themselves and convey their judgements, opinions, and commitments, stamping their personal au- 
thority onto their arguments or stepping back and disguising their involvement.

It is clear from the above information that the language of the newspaper is a component of journalistic style and is characterised as a complex phenomenon due to the multifaceted nature of its tasks, as well as its extralinguistic and linguistic features. Most researchers of the style of the newspaper (Erofeeva \& Ushnikova, 2017; Korolova, Popova, \& Ding, 2014) are inclined to think about its lexical and grammatical heterogeneity depending on the subject of articles. The most important feature of the newspaper genre is the combination of these functions: to inform the reader and to influence his / her opinion. The research material is analysed based on the abovementioned positions.

\section{Lexical Features of the Chinese Press}

Lexical and grammatical features of newspaper texts of the modern Chinese press deserve the special attention of researchers. In the system of lexical means of the journalistic style of modern Chinese, the following lexical units occupy an essential place:

- socio-political vocabulary and phraseology;

- socio-political terms;

- neologisms;

- 'fashionable' words;

- slogans;

- emotionally coloured vocabulary.

Social and political vocabulary is the core of the lexical framework of mass media. Changes in power, ideology, political system within a state inevitably lead to the emergence of new nominations of socio-political nature, which are constantly penetrating the media (Chinese Phraseology Dictionary, 1989, p. 96). The newspaper lan- guage generates vocabulary (lexical units) from all functional styles: scientific, official business, colloquial styles, and fiction due to the variety of topics and genres covered in the press.

The most commonly used units of sociopolitical vocabulary (commonly used in the Chinese periodicals) include these lexemes: 鼓动 / gǔdòng - агітаuіiя [Eng. agitation], 宣言/ xuānyán - деклараuіi [Eng. declaration; manifesto], 纲领 / gānglinng - програмa [Eng. program, platform (political, electoral)], 宣传/xuānchuán - пропаганда [Eng. propaganda, agitation], 职 工 / zhígōng - профспілка [Eng. trade union], etc. Lack of international words, which have constituted the Chinese language in the form of phonetic borrowings, is the characteristic feature of the Chinese socio-political vocabulary (e.g., 苏维埃/ sūwéi'āi-радянський [Eng. Soviet]).

The widespread use of terminological units (scientific, technical, economic, military, agricultural) is associated with the rapid development of the country's industry and its economic needs. The connection between the functioning of the Chinese national language and social spheres of life - industry, science, politics, and other spheres of human activities - are reflected in the language of newspaper texts. The social orientation of language is embodied in the functional versatility of the newspaper message and its pragmatic significance. It should be noted that socio-political and terminological vocabulary in the newspaper language is used in a direct (denotational), subject-centred, and logical meaning, which is characterised by unambiguity.

Wenyan words, or wenyanisms, [Chinese 文言 / wényán; English 'the literary Chinese'] play a certain role in Chinese journalistic written texts (alongside modern spoken Chinese). 'Wenyan' is a laconic and, at the same time, semanti- 
cally meaningful language. Therefore, wenyanisms are often used in modern journalism. Let us consider some examples.

1) 设宴/ shèyàn - влаштувати прийом, дати банкет [Eng. to arrange a reception, to hold a banquet]. This word combination is used instead of the phrase “摆酒席 / bari jiǔxi' with the same semantic meaning in modern spoken Chinese (白话 / báihuà).

2) 应邀 / yìngyāo - прийняти запрочення, на запрошення [Eng. to accept an invitation, at/by an invitation]. Compare with the semantically similar word combination used in modern spoken Chinese: 答应邀请 $d \bar{a}$ ying / yāoqing.

We should also take into account the fact that wenyanisms can create a certain solemnity, give the language a modal connotation of significance.

It should be borne in mind that emotionally coloured words are widely used in the Chinese media. Idiomatic expressions 成语 / chéngyŭ [Eng. Chinese set expression, typically of 4 characters, often alluding to a story or historical quotation; idiom; proverb; saying; adage (Big Chinese-Russian Dictionary, n.d.)], due to their original nature, usually give an original national colour to a journalistic work: e.g., 英勇 / yingyŏng - героїчний [Eng. heroic], 出色 / chūsèвидатний [Eng. outstanding; remarkable; splendid], 懦夫 / nuòfū - боягуз [Eng. coward; craven; weakling].

The use of the vocabulary constituting the high bookish style is also typical of the Chinese press: 伟大/wěidà-великий [Eng. great, mighty], 伟业 / wе̌iyè - велике діяння [Eng. great deed; great undertaking], 先生 / xiānsheng naн [Eng. mister; Mr.; gentleman; sir], 夫人 / fürén - naнi [Eng. Lady; Madame; Mrs.], 导师/ dăoshī- учитель, вождь [Eng. teacher; tutor; leader], 逝世/shishi-cмерть; померти [Eng. decease; to pass away; to die].

We are to mention a few words about the use of colloquial vocabulary in newspaper texts, which is associated with commonly used words that are not assigned to any of the styles. Those are the so-called multi-style words; they create the necessary neutrality of presentation. At their background, the stylistic characteristics of other words become more prominent. It is the neutral, multi-style vocabulary that provides for the unity of any language (including Chinese) as a system (Chinese Phraseology Dictionary, 1989, pp. 53$60)$.

Many neologisms have recently appeared in Chinese newspaper articles. It is worth highlighting that there is a new tendency in building neologisms: there are sound-imitating (onomatopoetic) or modal elements in their structure. We can give these examples:

3) 壁咚/ bì dōng (from Japanese 壁驵/ kabe dōng) - спосіб виразити свої почуття, зізнатися в любові: чоловік пригортає дівчину до стіни (壁/ bi), плескає по стіні рукою, видаючи звук “咚” / dōng (“тук”), і потім зізнається в коханні. [Eng. a way to express one's feelings, to confess one's love: a man pushes a girl against the wall (壁/ bi), slaps his hand on the wall, making a sound "rat-a-tat" ("咚) dōng”), then he confesses his love].

4) 花呗 / huā bei - фінансовий продукm, щэо дозволяє споживачеві брати кредит при здійсненні покупок через Iнтернет. 壁咚 / bi dōng originated from the consumer credit service offered by Ant Financial Services 蚂蚁金服 / Mă y̌ Jin fú (mobile app 
Ant Financial). [Eng. a financial product that allows the consumer to take credit when shopping online].

5) 萌萌哒 / méng méng dá - милиü, забавнuй. [Eng. (Internet slang) adorable, cute].

It seems significant to single out (among the neologisms) the words marked in the dictionary as '网络词语/ wăngluò cì' [Eng. 'Internet vocabulary']. That layer of language is very specific. On the one hand, it is a source of new vocabulary, and on the other hand, it is on the Internet where the already established vocabulary of normative Chinese is being transformed. Tendencies in the development of the Internet vocabulary differ from the tendencies regulating the development of the literary language vocabulary; in particular, this is manifested in word formation and the quantitative structure of words.

It is worth noting that many neologisms in newspaper texts are used in metaphors. Thus, the metaphorical neologisms found in the Chinese press can be divided into three groups: a) nominative, b) expressive, and c) sociolect-marked metaphorical neologisms.

\section{A. Nominative Metaphorical Neologisms}

6) 红 / hong (“她很红 / Tā hěn hóng”, “他是 个红人 / Tā shìgè hóng rén' ) - зірка; людина, що користується успіхом (фавором, любов'ю); видатний; популярний, знаменитий, коханий, модний (Khamatova, 1981, p. 474). [Eng. a star ('a very popular person', 'a celebrity'); a person who enjoys success (favour, love); outstanding; popular, famous; beloved; fashionable].

B. Expressive Metaphorical Neologisms

7) 土豪/ tǔ háo - багатий, щуо демонстративно витрачає гроші, але не має освіти, культурного виховання. In sentences:
“你是土豪! / Nǐ shì tǔháo”! - “Tu - zpoшовий мімок”! and “土豪, 请我吃饭 / Tǔháo, qǐng wǒ chïfàn”. - "Нувориш, заnроси мене на вечерю”. [Eng. 土豪/ tǔ háo - (slang) nouveau riche, money bag, local tycoon; a person who wastes money, though he/she is neither educated nor culturally brought up. In sentences: "You are a money bag"! and "Nouveau riche, take me to dinner'].

One can call this name a person from the lower strata of society, a person who won the lottery. For example, the Institute of Management at Zhejiang Ocean University is called ' $土$ 豪学院 / Tǔháo xuéyuàn' [Eng. institute - nouveau riche] because of a big number of parties, prizes and gifts. This expression has a negative connotation predominantly.

8) 菜鸟 / càiniăo - новачок, жовторотик: “你是个菜鸟 / Nì shìgè càiniǎo”. - “Ти новачок (у цій сфері)". [Eng. 'newbie', 'rookie', 'beginner': "You are a rookie (in this sphere)']. A newbie is compared with a small inexperienced bird. It may have both positive and negative connotations.

\section{Sociolect-Marked Metaphorical Neolo-} gisms

One of the examples is the word combination '白富美 / bái fùměi' (Khamatova, 1981: 412) - жарг. високі, красиві і успішні дівчата зі світлою шкірою (що особливо цінується в Китаi). - [Eng. (jargon) tall fair-skinned, rich and beautiful girls (who are valued in China)].

Modern Chinese vocabulary is replenished by means of borrowings. See the examples: 脸基 尼 / liăn jīní (from Eng. 'facekini') - фейскинi (купальник на обличчя від сонячних променів); 慕课 / mù kè (from Eng. MOOC (Massive Open 
Online Course) - масовий відкритий онлайн кypc; NINI 族 / NINI zú (from Span. 'ni estudian, ni trabajan') - молоді люди, які не навчаються і не працюють, живуть за рахунок батьків або соччіальної допомоги. - [Eng. Young people who neither study nor work; they live at the expenses of their parents or social financial support].

The designated lexical characteristics of the Chinese newspaper language are systemic because there are no 'impassable edges' between language means; they are connected by numerous relations, they are closely intertwined, and interact with each other; they are actualised in different forms of speech. The language of modern mass media (政论语体/ zhèng lúnyǔ tì) is a typical example of interaction and interpenetration of all lexical layers into the language of a newspaper text.

Thus, we can conclude that the Chinese newspaper-journalistic language as a medium is diverse; it is a synthesis of language units constituting all language levels. Lexico-phraseological units and phrases are actively used in it; they combine functional and expressive evaluative colouring, elements of foreign (borrowed) words, and neologisms that supplement the Chinese vocabulary (lexicon).

\section{Grammatical Features of the Chinese Press}

A newspaper is a periodical edition that covers public life and issues of current, everyday politics. The topics of the articles are relevant. It is always tendentious; it is always a product of one or another ideology. Therefore, articles of the newspaper genre are often propaganda-oriented and agitation-centred in their nature, which is actualised due to the strengthening of influence on the reader/listener through the correct (tactful) use of linguistic means. Grammatical units (morphological and syntactic levels) are among them too.

The Chinese newspaper text is characterised by peculiar grammatical features: simplifying syntactic forms and variability of morphological combinations. Some typical features of the syntactic framework of the newspaper-style are listed below:

- fixed word order in a sentence;

- a large number of complex, compound, and two-member simple sentences;

- wide use of connectors;

- lack of elliptical structures;

- use of all communicative types of sentences.

The recurrence of imperatives is one of the features marking the structure of the Chinese newspaper text, which strengthens the pragmatic orientation of the proposal. The functional role of the influence on the recipient is also enhanced by the use of emphasis in the syntactical structures of imperative sentences and rhetorical questions. Morphology is characterised by the use of normative word-forming forms, systematised categorical features of parts of speech, and the absence of elliptical speech expressions. It should also be noted that in newspaper texts, along with modern morphological forms, there are phrases consisting of four-morpheme elements, which are built according to the lexical and grammatical norms of the wenyan language. Here are some examples: 不言而喻 / bùyán éryù - зрозуміло без слів; само собою зрозуміло [Eng. it is selfevident; it goes without saying]; 一扫而空/ yīsăo ér kōng - разом і повністю ліквідувати [Eng. to eliminate completely and at once]; 求全 责备 / qiúquánzébèi - вимагати повної доско- 
налості; бути вкрай прискіпливим [Eng. to demand perfection]. Some of these word combinations are phraseological units. See the examples below.

9) “真是 可笑”! / “zhēnshì kěxiào”! - “Дiǔсно смішно (сміховино)"'! [Eng. "It is really funny (hilarious)"!]

10) “等着㫿吧”! - “děngzheqiáo ba”! - “Пoжсивемо - побачимо”! [Eng. "Wait and see (who is right)"!]

In newspaper articles, a method of emotional and logical selection of objects and borrowings from wenyan is used. This is a combination of the limiting particle '惟/ wéi' and the intensifying particle '是/shi'.

11)“这些文物一定要全部追回, 缺少任 何一件, 惟他们是 问”! / “zhèxiē wénwù yīding yào quánbù zhuīhuí quēshăo rènhé yījiàn, wéi tāmen shì wèn"! - "Уci ųi культурні реліквї неодмінно повинні бути відновлені. Лише чогось не вистачає, але вони дійсно викликають інтерес"! [Eng. "All these cultural relics must be restored. Only something is missing, but they are really interesting"!]

In newspaper materials, compositional methods of the reorganisation of grammatical structures are aimed at intensifying expressiveness. Consider the figures of speech given below.

12) “人民饿肚皮, 政客吹牛皮”. / “rénmin è dùpí, zhèngkè chuī niúpi”. - (газетна лексика) "Народ голодує, а політикани хваляться". [Eng. (newspaper vocabulary) "The people are starving while the politicians are boasting”]. The word “政客 / zhèngkè' - політикани [Eng. 'politicians'] has a negative emotional and attitudinal meaning.

13）“凡谈及古, 就眉飞色舞; 凡谈及今,
则百般 鄙薄”. / “fán tánjí 古, jiù méi fềi sè wǔ, fán tánjí jīn zé băibān bỉbó”. - (навчання) “Всякий раз, коли мова заходить про давність, відчувають неймовірний захват; всякий раз, коли мова заходить про сучасність, всіляко висловлюють свою зневагу”. [Eng. (learning) “Whenever it comes to antiquity, one feels incredible delight; whenever it comes to modernity, one expresses his / her contempt in every possible way"].

There might be a semantic difference between the corresponding pairs of words and phrases. It means that the words belong to the neutral vocabulary, whereas the phrases are used mainly in the written bookish style and have a modal connotative meaning. Study some other examples: 分析 / fēnxī - аналіз; аналізувати [Eng. analysis; to analyse], 加以 分析 / jiāyl fēnxī - nіддати аналізу [Eng. to undertake an analysis]; 逮捕 / dàibǔ - apewm; заapewmyвamu [Eng. an arrest; to arrest], 加以 逮捕 । jiāy̌̌ dàibǔ - niddamu apewmy [Eng. to undergo an arrest]; 压力 / yālì- тиск [Eng. pressure], 施加 压力 / shījiā yālì- чинити тиск [Engl. to exert pressure]; 帮助 / bāngzhù - допомога; допомагати [Eng. help; assistance; to help; to assist], 给以 帮助 / gěiy ǐ bāngzhù - нadamu допомогу [Eng. to provide assistance]. In the Chinese newspaper articles, the indefinite pronoun '什么/ shénme' [Eng. 'something'; 'some kind of'; 'somebody (someone)'] is used for the subjective transmission of somebody's speech/ words (in other words, indirect speech). In such cases, '什么 / shénme' expresses doubt or disagreement and corresponds to the Ukrainian particles 'нібито', 'мовляв', 'де' [Eng. 'allegedly', 'is/are said', 'like', 'where'].

14) “他们说什么这个会谈公报是非政 
府性说明, 妄想否定它的权威性”. / 'tāmen shuō shénme zhège huitán gōngbào shifêi zhèngfǔ xìng shuōmíng, wàngxiăng fŏudìng tuō de quánwēixìng”. - (газетна лексика) "Вони кажуть, що комюніке про переговори, мовляв, є неурядовою, заявою, марно намагаючись тим самим заперечувати його авторитетний характер”. [Eng. (newspaper vocabulary) "They say the communique on the negotiations is said to be a non-governmental statement; trying (in vain) to deny its authoritative nature”].

15) “有人正在对谈判放出悲观空气, 说 什么接受这一建议等于是可耻的投 降”. / “yǒurén zhèngzài duì tánpàn fàngchū bēiguān kōngqì, shuō shénme jiêshòu zhè ȳ̄ jiànyì děng yúshì kéchǐ de tóuxiáng”. - (газетна лексика) “Дехто створює навколо переговорів атмосферу песимізму, кажучи, щуо, мовляв, прийнятття иісї пропозичії рівносильне ганебної капітуляиіï”. [Eng. (newspaper vocabulary) "Someone is creating an atmosphere of pessimism around the negotiations, saying that accepting the proposal is tantamount to a shameful surrender'].

At the end of the twentieth century, the number of neologisms in the Chinese press increased cardinally; it accounted for almost 2,000 lexical units. A significant part of neologisms comprises compound words. The complication of the word's quantitative structure polysyllabism (increasing the number of three-, four-component lexemes, or more) contributes to the development of the new Chinese vocabulary (Vorotkov, 1968). The analysis shows that three-syllable compound neologisms dominate in the newspaper material: e.g., 单人族 / dān rén zú-люди, щэо воліють жити на самоті і стороняться інших людей [Eng. people who

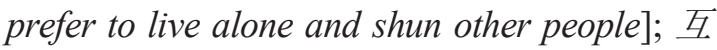
动码 / hùdòng biānmă - товари з двовимірним иттрих-кодом [Eng. goods with a two-dimensional bar code]; 流量币 / liúliàng bìвіртуальні гроші (Chinese Phraseology Dictionary, 1989; Sdobnikov, 2015) [Eng. digital/ virtual money].

Another productive way of word formation in modern Chinese is morpheme contraction creating new words due to the dropping out of specific significant components (morphemes) from compound words or terminological word combinations (Solntseva \& Solntsev, 1979). See the examples below.

16) 弃疗 / qiliáo from 放育治疗 / fàngqi zhiliáo - відмовитися від лікування [Eng. to refuse treatment]: 放 / fàng - 1) вidnycкати; випускати, звільняти; 2) розпускати; давати волю [Eng. 1) to release; 2) to dissolve; give free rein; give way]; 弃/ qi - кинути; залишити [Eng. to quit; to leave]; 治疗 / zhì liáo - 1) лікуватися; лiкувальний, циілющий, терапевтичний; 2) лікування, терапія [Eng. 1) be treated; curative, medicinal, therapeutic; 2) treatment, therapy];

17) 全深改/quán shēn găi from 全面深化改 革 / quánmiàn shēnhuà găigé - всебічне поглиблення реформ [Eng. comprehensive deepening of reforms]: 全面/quánmiàn всебічний, комплексний, повномасштабний, всеосяэний; загальний, повний, тотальний; вичерпний; всебічно, з усіх боків; у всіх відношеннях; повністю, в повному обсязі [Eng. comprehensive, fullscale; universal, complete, total; exhausttive; comprehensively, from all sides; in every way; completely, in full]; 深化 / shēn- 
hиа̀ - поглиблення; поглиблювати (ся)

[Eng. deepening; to deepen]; 改革/găigéреформувати, оновлювати; перетворювати; виправляти, змінювати; перетворення, реформа [Eng. To reform, to update; to transform; to correct, to change; transformation, reform];

18) 三项清单/sānxiàng qīngdān from 三项权 力 清单 / sān xiàng quánlì qīngdān - mpu види списків / реєстрів [Eng. three types of lists / registers]: 三项 / sānxiàng 1) тричлен; тричлен; 2) ел. трифазний [Eng. 1) trinomial; 2) electric three-phase]; 权力 / quánli - влада, могутність; повноваження [Eng. power; empowerment]; 清单 / qīngdān - перелік; (розрахункова) відомість; опис; реєстр; балансовий звіт, рахунок-фактура; докладний список [Eng. scroll; payslip; inventory; registry; balance sheet, invoice; detailed list].

Morpheme contraction is a reaction of language to increasing the number of complex word combinations, which manifests a 'natural desire' of language to save linguistic means.

The attributive (one element denotes the object itself and the other one - its feature) and the affix models are the most productive ways of creating neologisms in modern Chinese: 码农/ mănóng - програмicm [Eng. programmer]; 深 改 / shēn'găi - поглиблене проведення реформ [Eng. in-depth reforming]. We distinguish the

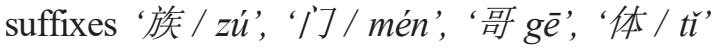
and the prefixes '神 / shén', ‘微/ weì' among the active word-forming elements. We should also mention these affixes and semi-affixes: '多/ duō', '高/gāo', ‘软/ ruăn', '大/dà', '热/ rè', '户/hù', ‘盲/máng', '坛/tán', '感/găn'.
Translation Peculiarities: "Reproduction" of the Chinese Press in Ukrainian

Another issue under study is the analysis of the translation operations, tactics, and strategies used in the reproduction of the Chinese newspaper texts in Ukrainian and contribute to the adequacy of translation of the original text into the target language. The analysed material demonstrated the peculiarities of displaying an original (source) text in a foreign (target) language at all language levels (phonetic, lexical, grammatical). So, let us consider them sequentially.

\section{A. Phonetic Level}

1. Transcription (reproduction of the sound form of the original word in translation) is widely used in the translation of proper names, geographical names, company names, printed editions, neologisms, etc. Study the examples: $B A T$ (contracted from 百度 / Băidù, 阿里 / Ālù, 腾讯 / Téngxùn the names of the biggest Internet-sites in China) - БАТ (Байду, Алі, Тенсюнь). Transcription allows us to concisely and laconically name a foreign lexical unit.

2. Transliteration (transfer of the graphic form of the original word in translation) is one of the most common ways of reproducing the original (source) word: e.g., 丁 克家庭 / Dīngkè jiātíng - сім'я ДІНК [Eng. D(ual) I(ncome) N(o) K(ids)], сім'я, що має доходи, але не бажає мати dimeŭ [Eng. (family) DINK; a member of a couple who both hold jobs and have no children]. This method, along with transcription, is the most common means of dis- 
playing foreign lexemes.

We share Tomasz Majtczak's (2019) opinion regarding the situation in which a certain language possesses no equivalent for a borrowing; "untranslatedness" would be a better term here than untranslatability.

\section{B. Lexical Level}

3. Loan translation (creation of an equivalent by compiling foreign equivalents of constituent word parts). The advantages of loan translation are its unambiguous correlation with the original word, which leads to complete reversibility of correspondence (equivalency). Although those equivalents 'suffer' from literalism, brevity and potential terminology make them suitable for texts of any genre. See the examples below.

19) 鸟它乌政/ Tuóniăo zhèng - 'страусина noлітика' [Eng. 'ostrich policy ]: [Eng. 鸟它乌 / Tuóniăo - African ostrich; 政 / zhèng 1) to manage; to govern; to reign; control; administration; 2) politics; political]. It is "a metaphoric expression referring to the tendency to ignore obvious matters and pretend they do not exist" (Klabbers, 2009, p. $11)$; the expression derives from the supposed habit of ostriches to stick their head in the sand rather than face danger (Mirani, 2015).

20) 桥牌 / Qiáopái - брідж (карткова гра) [Eng. the card game Bridge]: [Eng. 桥/ Qiáo - 1) bridge; 2) a canopy over the road; 牌/ pái-a bone for playing (domino, majiang); playing cards].

4. Concretisation, or specification, (replacement of a word or a phrase containing a word with a broader object-centred logical meaning by a translation match having a narrower meaning in the target language): e.g., 单身贵 / Dānshēn guì - ycnimнi молоді люди без партнера в житті; самотні аристократи (про холостяків) [Eng. successful young people without a partner in life (single young people); lonely aristocrats (about bachelors)] (Klyenin \& Shchichko, 1978).

5. Generalisation (replacement of a lexical unit of the original (source) language, which has a narrower meaning, with a lexical unit of the target language having a broader meaning): e.g., 大会 / dàhuì заключна конферениія [Eng. closing conference; 大会/ dàhuì is translated - 'meeting; congress; plenum; assembly, congress ].

6. Explication (replacement of a lexical unit of the original (source) language with an appropriate explanation in the target language, which reveals its meaning). The disadvantage of descriptive translation is its verbosity: e.g., “行行出状元 / Háng háng chū zhuàngyuán" (Chinese Phraseology Dictionary, 1989: 342) - у кожній професії є свої фахівці (таланти, умільці) [Eng. every trade has its master; one may distinguish himself in any trade].

7. Word-for-word-translation (reproduction of the combinatorial syllable of a word or a phrase in which the constituent parts of a word (morpheme) or a phrase (lexeme) are rendered into the target language through corresponding elements composed of the translated parts without any changes) restores the original cultural message, which is usually extremely difficult to do in translation. According to these features, the use of this translation method is very rarely 
used due to the originality of the linguistic and cultural features of each nation: 春节/ Chūnjié - Чуньизе - весняне свято [Eng. The Spring Festival]. Here are some more examples of word-for-word translation related to the cultural characteristics of China. As you know, the Chinese celebrate the New Year holiday according to the Eastern lunar calendar. Accordingly, many New Year's neologisms are associated with the peculiarities of the chronology system (time reckoning): e.g., 除夕 / chúxì - Yyci- - aпередодні Нового року; ніч під Новий рік [Eng. New Year's Eve; verbatim: 除/ chúa year which is going to be over; 夕/ xìthe last evening of the year]; 元旦 / yuándàn - перший день Нового року [Eng. New Year's Day; verbatim: 元/yuán - the beginning of the chronology; era; first (e.g. about a year, a month, a day); 旦/ dàn - 1) morning, dawn; at dawn; early in the morning; morning; 2) day, daytime; in the afternoon]; 正月初 / zhèngyuè chu - nepший місяцьь нового року [Eng. the first month of the year], etc.

It is also necessary to say a few words about numerous neologisms related to the people's activities on holidays. Consider the examples below.

21) 贴倒福 / tiē dào fú - клеїти догори ногами ієрогліф 'щастя' [Eng. 贴 / tie - to glue, to stick on; 倒/ dào - to invert; to pour out; 福/fú-happiness; well-being; verbatim: 'to glue the Chinese character 'happiness' upside down']. The Chinese create the designated kind of hieroglyph (Chinese character) to bring happiness to the house.

22) 春运/ chūnyùn-mранспортне і пасажирське 'стовпотворіння' [Eng. passenger and traffic 'jam'; verbatim: 'spring movement/travel']. Spring travels (migrations) occur on the eve of the Chinese New Year; they cause significant difficulties and problems connected with moving within the regions and the country as a whole, buying tickets, finding available flights and trains, etc.

The main ways of translating the Chinese newspaper articles into Ukrainian (at the phonetic and lexical levels) are as follows: descriptive translation $(30.3 \%)$, concretisation $(24.6 \%)$, transliteration (13.1\%), loan translation (13.0\%), word-for-word translation (12.7\%), transcription $(5.2 \%)$, generalisation $(1.1 \%)$. It should also be taken into account that there is a combined method of using translation operations (transcription and loan translation, transcription and explanation, loan translation and explanation), which is a productive and effective translation tool.

\section{Grammatical Level}

At the grammatical level, when translating the Chinese press, we deal with two most frequently used translation operations: functional substitution and conversion.

8. Functional substitution (replacement) or adequate substitution (replacement) (sentence segmentation, compression of a complex (or compound) sentence, the substitution of a complex (or compound) sentence by a simple one / ones, replacement of a conjunctive type of connection with a non-conjunctive one): e.g., 一样 (达尔礼 品 广告) / yīyàng (dá'ěr lǐpǐn guănggào) - рідкісний $і$ безцінний дар, як $і$ жінка, яку ви кохаєте [Eng. a rare and priceless gift, like the woman you love]. Replacement of the syntactic construction of a sentence is very common when translating 
newspaper and information texts from Chinese into Ukrainian. Study the examples below:

23) This is how a travel company advertises a trip to Hong Kong: “香港是一个唯一可 以将东方现代化色彩与中国”. / “Xiānggăng shì yìgè wéiȳ kěyı̌ jiāng dōngfāng xiàndàihuà sècăi yǔ zhōngguó". - "Гон-

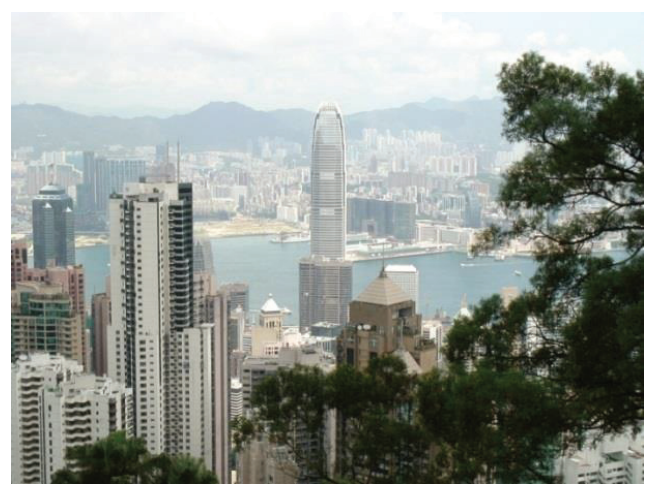

Illustration 2. Morning in Hong Kong

24)“发布会上、同时举行了中国邮政集团 2016 《拜年》主题邮票、《中华春节吉 祥物全球发布》纪念封发行仪式”. / "Fābù hui shàng, tóngshi jǔxíngle zhōngguó yóuzhèng jituán 2016 bàinián" zhǔtí yóupiào, zhōnghuá chūnjié jíxiáng wù quánqiú fābù "jìniàn fēng fâxíng yíshì. "Під час конферениії відбулася иеремонія презентації китайською поштовою службою вітальної новорічної марки 2016 року, щзо має сприяти популяризамиї талісманів китайського Нового року у всьому світі". [Eng. "During the conference, China Post held a ceremony to present the 2016 New Year's greeting stamp, which is to promote the Chinese New Year mascots around the world"].

As we can see from the above examples, functional substitution is based on the semantic and structural features of the two languages un- конг - перлина Сходу" (see Illustrations 2, 3). [Eng. "Hong Kong is the pearl of the East']. The beauty of Hong Kong is compared to a white and, at the same time, shiny pearl. The before mentioned word has a nominative character and fulfils an expressive aesthetic function.

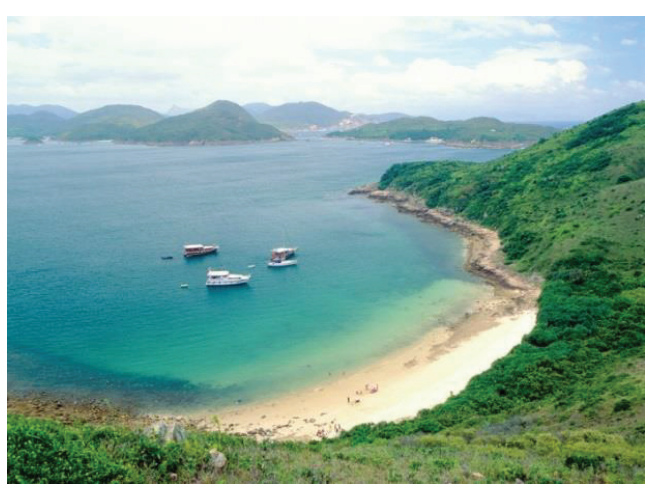

Illustration 3. Quiet Harbour ${ }^{2}$

der study. Besides, there are also these translation operations: additions, omissions, and many other ones.

9. Conversion (replacement of the grammatical form of the source language lexemes with the corresponding one in the target language) is used when the degree of explicitness of the message elements in the source language and the target language does not coincide: e.g., 公主病 / gōngzhǔ bìng - 'мати корону на голові' (про зарозумілу дівчину) [Eng. 'to have a crown on the head' (about an arrogant girl) = 'princess syndrome'; verbatim: 'princess sickness'].

The study and analysis of the research material enabled us to assume that morphological

Pictures are available at: https://tonkosti.ru/\%D0\%93\%D0\%BE\%D0\%BD $\%$ D0\%BA $\%$ D0\%BE $\% \mathrm{D} 0 \% \mathrm{BD} \%$ D0\%B3. 
transformations have the least impact on the quality of translation because they do not change the semantic component of the text. They depend mainly on the translator, his / her experience, knowledge of linguistic rules regarding combinability of parts of speech. Morphological transformations are often combined with syntactic changes. Syntactic translation operations should be interpreted as modifications that do not involve a significant change in the content of the source text.

\section{Conclusion}

The analysis of the research material provided an opportunity to come to the following conclusions. In the modern world, there is an active development of cultural and languagerelated contacts between Ukraine and China, which requires translation for intercultural communication and dialogue. Considering the press as a special way of informing and influencing the audience, we can definitely assume that the journalistic style is associated with the social spheres of China's life: industry, science, politics, etc. The social orientation of the newspaper language, the connection of language with the public sphere reflect the lexical and grammatical composition of the journalistic, scientific and colloquial styles.

The initiated analysis of the linguistic features of newspaper texts (being of socio-political nature) made it possible to conclude that the functioning of the lexical, grammatical and phonetic levels has a systemic nature. The study of the lexical layer of modern Chinese has demonstrated the frequent use of socio-political lexemes, terminological units, neologisms. However, we should confirm an almost complete absence of international words and borrowings.
Among the grammatical features of the Chinese press, we single out these ones:

- at the syntactic level - direct speech, interrogative and imperative sentences, which contributes to the pragmatic orientation of the newspaper material under study and the solution of a specific problem;

- at the level of morphology - the use of phraseological units (成语 / chéngyǔ), which is associated with the isolating type of Chinese, the use of predicates functioning as the objects and adverbial modifiers;

- the most common phonetic means include transcription and transliteration, which are common means of reproducing foreign lexemes.

The study of translation features aimed at adequate reproduction of the Chinese press in the Ukrainian language has demonstrated the regularities as follows:

1) the use of the strategy of communicatively equivalent translation in order to create an adequate text in the target language;

2) the use of the tactics of cultural adaptation, correct text framework, pragmatic adaptation of the text, stylistic adaptation of the text, reproduction of formal and structural characteristics, domestication of the source text;

3) the use of the following translation operations: explication, loan translation, concretisation, transliteration; the less used ones transcription and word-for-word translation.

Thus, the initiated research made it possible to find out that achieving a successful intercultural communicative act involves a general programme of translator's actions; the choice of appropriate strategies, tactics (interpreted as a set of tools and techniques used to achieve this goal), 
and operations (means of overcoming difficulties in translating, which may arise during the translation). It was determined that the reproduction of communicatively equivalent translation involves the fullest possible preservation (by the translator) of the original information laid down by the author in the source text, the genre of the text, and its pragmatic orientation.

The perspectives of further research are seen in the study of the linguistic features of the Ukrainian press and translation means when reproducing newspaper texts from Ukrainian into Chinese.

\section{References}

Bandurski, D. (2010). Who is 'Zheng Qingyuan'?. China Media Project. Hong Kong: University of Hong Kong Journalism \& Media Studies Centre.

Big Chinese-Russian Dictionary. (n.d.). Retrieved from https://bkrs.info/.

Campbell, C. (2017). World Press Trends 2017. Frankfurt: WAN-IFRA. Retrieved from https://books.google.com.ua/books?id= 7otLDwAAQBAJ\&pg $=$ PA175\&lpg $=\mathrm{P}$ A175\&dq=Campbell,+Cecilia. $+2017 .+$ World+Press+Trends+2017.+Frankfurt $:+$ WAN-IFRA.\&source=bl\&ots=NeeFpeSYkb\&sig=ACfU3U39okBC-T1tEbMANU2cBmhrc1aJ6Q\&hl=ru\&sa$=$ X\&ved=2ahUKEwiHxJWym-3qAhUH0aYKHe64D6EQ6AEwEXoECAo $\mathrm{QAQ} \# \mathrm{v}=$ onepage $\& \mathrm{q}=\mathrm{Campbell} \% 2 \mathrm{C} \%$ 20Cecilia.\%202017.\%20World\%20Pre ss\%20Trends\%202017.\%20Frankfurt $\% 3 \mathrm{~A} \% 20 \mathrm{WAN}-$ IFRA.\&f=false.

Chinese Phraseology Dictionary. (1989). Pekin:

Beijing: People's Publishing House.

Combley, R. (Ed.). (2011). Cambridge Business
English Dictionary. Cambridge: Cambridge University Press.

Deng, Ya., \& Liu, R. (1989). Language and Culture. Beijing: Foreign Language Teaching and Research Press.

Doyle, Ch. (2011). A Dictionary of Marketing. ( $3^{\text {rd }}$ ed). Oxford: Oxford University Press.

Ebrey, P. B. (2010). The Cambridge Illustrated History of China. Washington: University of Washington.

Eilders, Ch. (2016, January 04). Print Media. Retrieved from https://onlinelibrary.wiley.com/doi/epdf/10.1002/9781118541 555.wbiepc193.

Erofeeva, I., \& Ushnikova, O. (2017, December). Media Text Energy as Collective Cultural Memory Reflection. Lege Artis. Language Yesterday, Today, Tomorrow. The Journal of University of SS Cyril and Methodius in Trnava, II(2), 1-46. doi:10.1515/lart-2017-0012.

Frolova, O. P. (1981). Word Formation in the Terminological Vocabulary of the Modern Chinese Language. (M. I. Cheremisina, Ed.). Novosibirsk: Science. Siberian branch.

Gitter, D., \& Fang, L. (2018). The Chinese Communist Party's Use of Homophonous Pen Names: An Open-Source Open Secret. Asia Policy, 25(1), 69112. doi:10.1353/asp.2018.0009.

Guo, Ch., \& Liu, F. (1997). A Dynamic Research into L1 Influence on L2 Writing. Modern Foreign Language, 4, 30-38.

Hovhannisyan, H., Hovhannisyan, H., \& Petrosyan, A. (2018). Young Professionals' Labour Market Integration Issues in Armenia: A Case Study with Special Reference to Alumni of Armenian State 
Pedagogical University. Wisdom, 2(11), 42-52.

Khamatova, A. A. (1981). Homonyms in Modern Chinese. Vladivostok: Far Eastern State University.

Klabbers, J. (2009). Treaty Conflict and the European Union. Cambridge: Cambridge UP.

Klyenin, I. D., \& Shchichko, V. F. (1978). Leksikologiya i frazeologiya kitaiskogo yazy$k a$ (Chinese Lexicology and Phraseology: A Lecture Course, in Russian). Moscow: Military Institute of Foreign Languages.

Korolova, T., \& Aleksyeyev, O. (2018). Osoblyvosti perekladu tradytsijnoho kytajs'komovnoho medychnoho dyskursu ukrayins'koyu ta anhlijs'koyu movamy (Specificities of Translating Traditional Chinese Medical Discourse into Ukrainian and English, in Ukrainian). Scientific Research Issues of South Ukrainian National Pedagogical University named after K. D. Ushynsky: Linguistic Sciences, 26, 95-104. doi:10.24195/2616-5317-2018-26-12.

Korolova, T. M., Popova, O. V., \& Ding X. (2014). Translation of Official Documents. Odesa: INVATs.

Macmillan English Dictionary. (n.d.). Retrieved from https://www.macmillandictionary.com/dictionary/british/the-print-media.

Majtczak, T. (2019). Translating the Untranslatable: A Yiddish Text in Japanese Rendering. Studia Linguistica Universitatis Iagellonicae Cracoviensis, 136, 297307. doi:10.4467/20834624SL.19.022.11315.

Mirani, L. (2015). Fantastic Words with no Easy
Translation in other Languages. Quartz. Retrieved from https://qz.com/396076/tretar-tsundoku-jugaad-and-otheruseful-but-untranslatable-words-fromaround-the-world/.

Mirzakhanyan., R., Gevorgyan, S., Karapetyan, V., Dallakyan, A., \& Berberyan, A. (2019). Typical Expression of Cognitive Dissonance and Consonance in the Course of Argumentation among Primary-School Children Playing Chess. Wisdom, 2(13), 75-84.

Moratón, L., \& Lavid, J. (2018). Stance and Engagement in English and Spanish Journalistic Texts: Towards a Reliable Annotation Scheme for Linguistic and Computational Purposes. Studia Linguistica Universitatis Iagellonicae Cracoviensis, 135, 29-45. doi:10.4467/20834624SL.18.003.8163

Needham, J. \& Tsien, T.-H. (1985). Science and Civilisation in China: Volume 5, Chemistry and Chemical Technology. Part 1. $\left(3^{\text {rd }}\right.$ ed.). Cambridge: Cambridge University Press.

Oxford Reference. (n.d.). Retrieved from https://www.oxfordreference.com/view/10.10 93/oi/authority.20110803100346392.

Pavlik, J., \& McIntosh, Sh. (2017). Converging Media: A New Introduction to Mass Communication. New York: Oxford University Press.

Polishchuk, O., Vitiuk, I., Kovtun, N., \& Fed, V. (2020). Memes as the Phenomenon of Modern Digital Culture. Wisdom, 2(15), 45-55.

Popova, O. V. (2019). Taktyko-operatsijnyj konstrukt $u$ vidtvorenni zmistu akademichnoho dyskursu (na materiali anhlijs'koyi, kytajs'koyi ta ukrayins'koyi mov) 
(Tactical-Operational Corpus in Reproducing the Academic Discourse Content (On the Material of the English, Chinese and Ukrainian Languages), in Ukrainian). Scientific Research Issues of South Ukrainian National Pedagogical University named after K.D. Ushynsky: Linguistic Sciences, 28, 49-162. doi:10.24195/2616-5317-2019-28-14.

Printing Press. (2018, May 7). Retrieved from https://www.history.com/topics/inventi ons/printing-press.

Ruda, N. V. (2017). Strukturno-semantychni osoblyvosti bahatokomponentnykh skladnykh rechen' u kytajs 'kij movi (Structural and Semantic Features of Multicomponent Complex Sentences in Modern Chinese, in Ukrainian). (PhD thesis, Taras Shevchenko National University of Kyiv).

Samovar, L. A., Porter, R. E., \& Stefani, L. A. (2000). Communication between Cultures. Beijing: Foreign Language Teaching and Researching Press.

Sdobnikov, V. V. (2015). Kommunikativnaya situatsiya kak osnova vybora strategii perevoda (The Communicative Situation as the Basis for Choosing a Translation Strategy, in Russian). (Doctoral dissertation, Nizhny Novgorod Dobrolyubov State Linguistic University). Retrieved from http://www.dslib.net/sravnit-jazykoved/kommunikativnaja-situacija-kak-osnova-vybora-strategii-perevoda.$\underline{\mathrm{html}}$.
Solntseva, N. V., \& Solntsev, V. M. (1979). Teoreticheskaya grammatika sovremennogo kitaiskogo yazyka: Problemy morfologii (Theoretical Grammar of Modern Chinese: Problems of Morphology, in Russian). Moscow: Military Institute.

Spielvogel, J. J. (2010). Western Civilization. Retrieved from https://courses.lumenlearning.com/suny-hccc-worldhistory/chapter/the-printing-revolution/.

Steinberg, S. H., \& Warde, B. (2017). Five Hundred Years of Printing. New York: Dover Publications Inc., Mineola.

Vorotkov, N. N. (1968). Osnovnye osobennosti morfologicheskogo stroya kitaiskogo yazyka: Grammaticheskaya priroda slova (The Main Features of the Morphological Structure of the Chinese Language: The Grammatical Nature of the Word, in Russian). (11 ${ }^{\text {th }}$ ed.). Moscow: Science.

World Trends in Freedom of Expression and Media Development Global Report 2017/2018. UNESCO. (2018). Retrieved from https://unesdoc.unesco.org/ark:/48223/pf0000261065.

Your Dictionary. (n.d.). Retrieved from https://www.yourdictionary.com/printed-press.

Zhang, J., Anderson, R. C., Li, H., Dong, Q., Wu, X., \& Zhang, Y. (2010). CrossLanguage Transfer of Insight into the Structure of Compound Words. Reading and Writing, 23, 311-336. 